\title{
Development of Education for Indigenous Minorities in Alaska
}

\begin{abstract}
The history of development and modern forms of functioning of education for indigenous minorities in Alaska reveal trends which appeared in other areas of the Arctic. The systematic activity of education, along with the influence of other state institutions (military, offices), and also the often destructive influence of religious organizations contributed to irreversible changes in the ethnic awareness of indigenous communities. They have resulted in permanent changes in the ethnic identity of peoples inhabiting the Arctic for thousands of years. Initially, education was used by churches in the process of Christianization. Then, education was used to indoctrinate state ideologies (in particular national ones). And although currently various ethnic and national groups in the areas of the High North have opportunities in the sphere of using their own language and protecting their identity, the criteria for social promotion through the education system have remained unchanged. As a consequence, even representatives of large ethnic groups are determined - in their education and life choices.

Nowadays, the drama of indigenous minorities living in Alaska and other minorities in the polar regions continues, and we cannot expect it to end in a "constructive" manner. The dilemma of "preserving identity" in the conditions of a multi-ethnic society does not lose its focus. Individuals from indigenous communities usually have to choose between achieving educational and socio-professional success (as part of the dominant majority system) and the attachment to their traditional culture.
\end{abstract}

Keywords: Alaska, education, language, indigenous, minorities, assimilation, discrimination

\section{Introduction}

Alaska is the forty-ninth state of the United States, the area of which is five times larger than the territory of Poland. Its name comes from the Aleut language - "Alayeksha", which means "Great Earth". Currently, Alaska has several major urban centers - Anchorage,

1 JAHN, A., Alaska, Warsaw 1966, p. 9. 
Fairbanks, Juneau, Sitka, Kenai, as well as approximately twenty smaller towns and one hundred and eighty settlements. Alaska is the largest US state in terms of area, and the least populated. The territories of the state of Alaska have been a place of residence for various indigenous communities for millennia. Nowadays, however, as a result of mass migration processes, indigenous people constitute only a quarter of the population of this state $^{2}$.

Alaska is populated by a very diverse ethnic and linguistic indigenous group ${ }^{3}$. It is also inhabited by many other ethnic groups, many of whom are immigrants. Currently, there are approximately 138,000 ingenious people in Alaska, which is approx. $24.2 \%$ of the total population ${ }^{4}$. The largest indigenous groups are the Jupik Eskimos (33 889 people) and Inupiak Eskimos (33 360 people), as well as Tlingit-Haida Indians (26 080 people), Athabaski Indians - living in Alaska (22 484 people) and the Aleut (19 282 people) $)^{5}$.

The cultural and linguistic area is very diverse. Alaska is inhabited by representatives of different ethnic groups, differing in origin, history, culture and beliefs ${ }^{6}$, and now also the degree of acculturation ${ }^{7}$. It should be noted that even within these groups, many sub-groups are distinguished, which originated from old tribes, communities or regional groups. For example, within one ethnic group - the Iñupiaq Eskimos, E. S. Burch distinguished eleven subgroups living in the mid-nineteenth century in North-western areas of Alaska ${ }^{8}$.

Also in the linguistic sphere, there are clear differences - both in terms of the functioning of separate languages and in the sphere of the occurrence of individual dialects. The indigenous population is often divided into three main groups - depending on the language, culture and place of residence (Eskimos, Indians and Aleuts). Within these groups, there are four major language families (Eskimo-Aleutian, Atapascan-Eyak-Tlingit, Tsimshian and Haida) that form twenty separate languages?.

The peoples living on both sides of the Bering Strait were in permanent contact with each other. For example, the Inuit tribe (Eskimo) inhabiting Alaska was visited by Siberian Chukchi. The goal was primarily the exchange of goods. Czukchi offered steel and tobacco to the Inuit, as well as the skin of the reindeer, exchanging their products for prod-

2 NORRIS, T., VINES, P.L., HOEFFEL, E.M., The American Indian and Alaska Native Population: 2010, p. 7, 2010 Census Briefs, United States Department of Commerce Economics and Statistics Administration, U.S. Census Bureau,website: http://www.census.gov/prod/cen2010/briefs/c2010br-10.pdf.

3 See. KRAUSS, M. E., Alaska Native Languages: Past, Present, Future, Fairbanks 1980, p. 15.

${ }^{4}$ NORRIS, T., VINES, P.L., HOEFFEL E.M., The American Indian..., p. 7.

5 Ibidem, pp. 18-19.

6 JAHN, A., Alaska..., pp. 197-207.

7 GRABURn, N.H.H., STRONG, B.S., Circumpolar Peoples: An Anthropological Perspective, "Pacific Palisades" 1973, p. 183.

8 BURCH, E.S., The Iñupiaq Eskimo Nations of Northwest Alaska, Fairbanks 1998, pp. 8-12.

9 BARNHARD, C., A History of Schooling for Alaska Native People, ,Journal of American Indian Education" 2001, vol. 40, no 1, p. 2. 


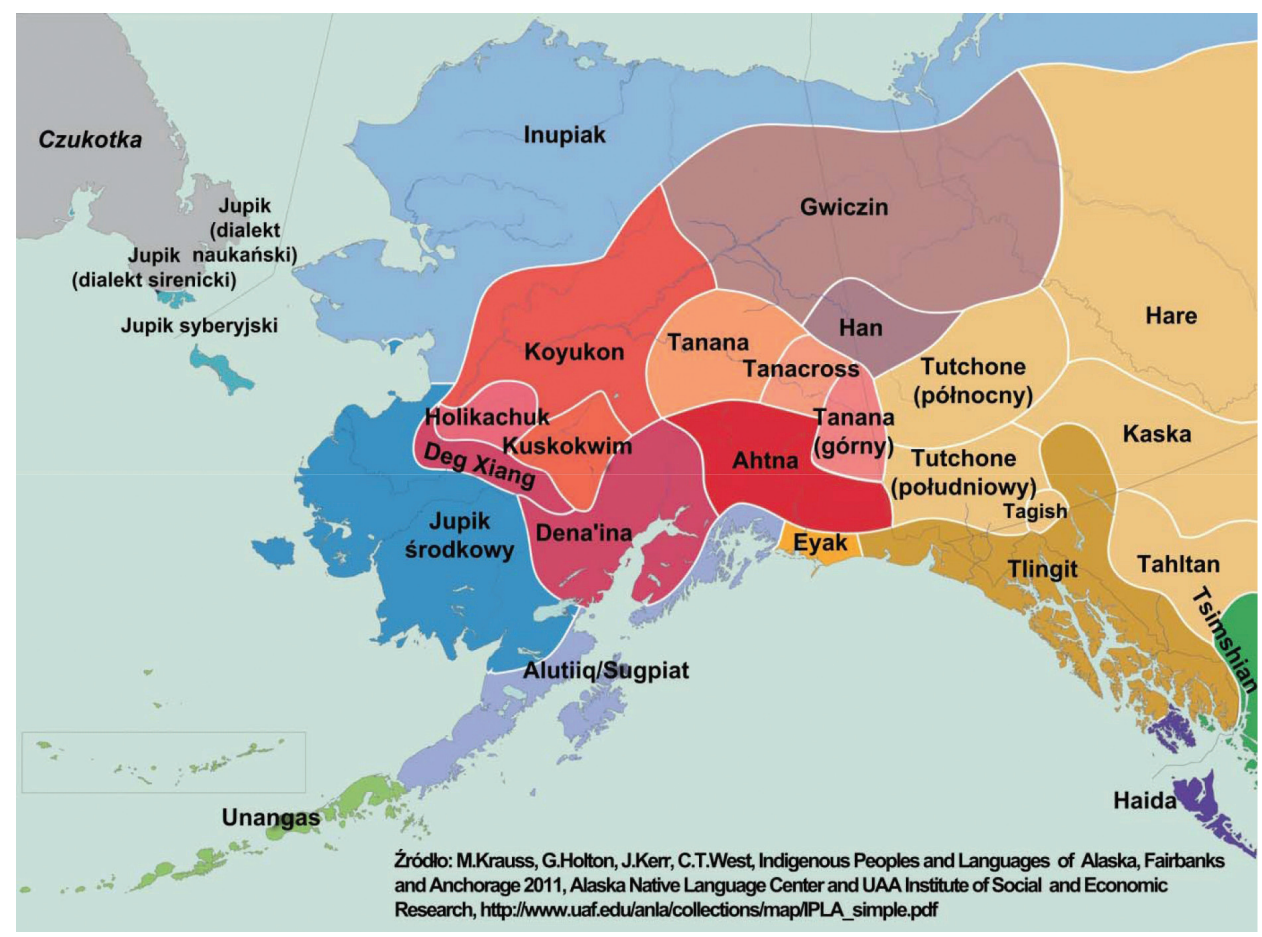

Map 1. The localization of indigenous peoples and languages in Alaska

ucts from marine mammals, nephrites, as well as animal fur. The natural boundary of the Bering Strait was not a barrier, but a route enabling mutual contacts ${ }^{10}$.

Beliefs of different ethnic groups living in Alaska are a separate area of research. Their similarity and diversity are a field for many analyses and scientific debates. The diversity of these beliefs, their complexity is proof of the highly developed metaphysical and cultural world of ethnic groups inhabiting the northern areas ${ }^{11}$.

This also applies to the Eskimo communities living in the Bering Sea area who have developed a complex belief system in which shamanism played an important role ${ }^{12}$. The Inuit economy (as well as other indigenous Alaska communities) was closely linked to the cycle of seasons. Spring began the traditional cycle of hunting and gathering food for the long winter months. The traditional element of the hunter's equipment was a kayak [qayaq]. An important means of transport were also larger boats, the so-called umiaks. Such boats could accommodate about 10-15 people with their belongings and dogs.

${ }^{10}$ ROWLEY, S.D.M., Inua: Spirit World of the Bering Sea Eskimo, Washington 1988, pp. 7-8.

11 See. WALENDZIAK, T., Eskimosi, the series Mitologie Świata, Warsaw 2008, pp. 15-20, and OLCHOWIK-ADAMOWSKA, L., BIERNACKA, E., Indianie Ameryki Pótnocnej, the series Mitologie Świata, Warsaw 2007, pp. 9-10.

12 ROWLEY, S.D.M., Inua: Spirit World..., pp. 63-69. 
They were used to move larger groups, change the place of the camp, visiting, etc. They made transport much easier, because moving long distances by land was associated with preparing the dogs and carrying luggage on the back. In certain regions (e.g. the Seward Peninsula), umiaks were also used for hunting for Beluga whales and walruses ${ }^{13}$.

Eskimos living in Alaska lived in huts made of wood, stone and peat. In some places, in winter camps, men lived separately in the so-called qasgiq. These were larger wooden houses, places of social gatherings and community life. Some of them were covered with a layer of peat soil for insulation against cold. In exceptional cases, women and children could also sleep in them. In the summer people lived in other types of houses (these were usually more spacious and brighter huts made of wood or tents made of caribou fur or sealskins $)^{14}$.

The specific habits and beliefs of the Inuit concerned every sphere of life. Children came to the world in a separate place near the place of residence of the family. In the winter it was usually a snow igloo, while in the summer a small tent from skins. According to Eskimos' beliefs, the new-born child had a body (timi), soul (iñussiq), life/breath (anigniq) and personality (ilitqusriq), but no name (atiq). As E. S. Burch points out, without a name, it was not fully human. Giving the name was one of the first important tasks of the community towards its new member. The name was usually given by family members (mother, father, grandparents, or close relatives) and it was usually a name after a deceased relative. All names were gender neutral. The practice of giving names led to the tendency of giving specific names depending on individual communities; an individual who had this knowledge could guess where the person came from based on his/her name. Iñupiat from the areas of north-western Alaska did not calculate the individual's age in years. The characteristics concerned the maturity of an individual to take specific roles in a tribal community ${ }^{15}$.

Socialization in the Alaskan Eskimo communities was related to everyday life. Gradually, the roles of children were differentiated according to gender. The girls undertook activities related to the preparation of food, preparation and sewing of skins, or setting traps for tundra ptarmigans and hares. Boys, on the other hand, undertook tasks related to hunting expeditions and the learning of hunting ${ }^{16}$. At the same time, it should be noted that the division of roles was not clearly defined (e.g. it happened that women participated in hunting expeditions). In addition, women (though less often than men) took on the role of shamans. Also, as E. S. Burch points out, many of the most powerful shamans were women ${ }^{17}$.

13 Ibidem, p. 19.

14 Ibidem, pp. 55-56.

15 BURCH, E.S., Social Life in Northwest Alaska. The Structure of Iñupiaq Eskimo Nations, Fairbanks 2006, pp. 58-59.

\footnotetext{
16 Ibidem, p. 59.

17 Ibidem, p. 65.
} 
Nowadays, accelerated modernization processes have resulted in rapid assimilation of indigenous communities into the mainstream of American culture. This results in the progressive disappearance of traditional customs, as well as changes in the systems of values that have been created and observed by indigenous communities for hundreds of years. At the same time, significant dynamics are visible in the sphere of the disappearance of native languages in Alaska.

\section{Educational assimilation policy in Alaska}

The colonization of Alaska began with expeditions undertaken via the Bering Strait. In the sixteenth century, Russian fur traders went mainly to the coast of Siberia, rarely entering into contacts with the Inuit living in Alaska. Vitus Bering, whose expedition was organized by Tsarina Catherine, discovered the Aleuts ${ }^{18}$. The expansion of Russian explorers and traffickers into the Aleutian Islands caused a significant extermination of the native population, as a result of fighting and brought numerous diseases ${ }^{19}$. The destruction was complemented by the plundering exploitation of natural resources (including the extermination of animals for fur $)^{20}$.

Also, the beginnings of educational activity in Alaska are associated with the processes of colonization of these areas by white settlers. This was characterized by the brutality of colonizers against indigenous communities. In 1784, a Russian fur trader, Griegorij Szelichov, established a trading post in today's Three Saints Bay on the southwest coast of Kodiak Island. He murdered a significant number of indigenous inhabitants of the area, taking the remaining captives. At the same time, creating the basis for ruling the island, he opened a school for indigenous children, in which he taught "Christian morality", arithmetic and the Russian language ${ }^{21}$. This institution gave rise to missionary schools created after the arrival in 1796 of the Orthodox missionaries in Alaska. Christianization of Eskimos in Alaska already began in tsarist times. In 1845, further missions of the Orthodox Church were founded. Nowadays, many Inuits (Jupik) still belong to the Russian Orthodox Church $^{22}$.

The creation of new mission schools took place in areas where Russian fur trading companies were operating (in particular on the Aleutian Islands, Kodiak Island, as well as on the areas of the Alaska peninsula and its south-eastern part). Russian monks and nuns undertook efforts to master the languages of indigenous communities and on this basis

18 ROWLEY, S.D.M., Inua: Spirit World..., p. 7.

19 JAHN, A., Alaska..., p. 225.

${ }^{20}$ GRABURN, N.H.H., STRONG, B.S., Circumpolar Peoples..., p. 133.

${ }^{21}$ Report of the Education task Force, Alaska Natives Commision/Alaska Federation of Natives, 1995, [in:] Alaska Native Education. Views From Within, ed. BARNHARDT, R., KAWAGLEY, A.O., Fairbanks 2010 , p. 7.

${ }^{22}$ Ibidem, p. 8. 
created a system of writing (for this purpose they used the Cyrillic alphabet). The aim of the Orthodox missionaries was not to eliminate the minority languages, but to use them to Christianise and eradicate the original religious practices (e.g. shamanism). In addition, as M. S. Williams points out, they often opposed the ill-treatment of indigenous peoples by Russian colonizers and representatives of fur companies who practiced slavery and committed rapes ${ }^{23}$.

On the other hand, the coastal areas along the Bering Sea (between the Yukon and Kuskokwim rivers) inhabited by largely dispersed populations of the Jupik Inuit were colonized much later. In practice, it was only in the 1880s that the arrival of Catholic and Moravian missionaries lay at the foundations of changes in the way minorities functioned in these areas. One of the reasons for the deep demographic crisis were diseases brought by white people. In 1900, the flu epidemic killed over half of the population of the region, and although the small communities on the coast were not affected so much, most of the winter settlements were destroyed. Another cause of change in lifestyle was the gold rush at Nome. It is worth noting, however, that populations inhabiting the settlements on the Bering Sea coast largely resisted the of ways of living and farming imposed by the church and state institutions until the first post-war decades ${ }^{24}$.

The arrival of American missionaries in the 1880s and 1890s (mainly Presbyterians, Quakers, Baptists and Catholics) changed the attitude towards indigenous communities in Alaska. Indigenous languages became the subject of attacks, and the purpose of the missionaries was to eliminate their use. At the same time, they perceived music and dance as well as shamanism as dangerous and devilish; racist, ethnocentric descriptions of indigenous peoples of Alaska, which obviously legitimized the brutal means used by missionaries in the processes of Christianization, were commonplace. The only recognized language was English. Moravian missionaries, on the other hand, who began their activities in the area of the Yukon-Kuskokwim delta in 1885, considered it necessary to use the Jupik language in the processes of evangelization. Consequently, also today in the towns where the Moravian missions were active, the Jupik language has a strong status ${ }^{25}$.

As a result of this policy, the use of native Alaska languages was forbidden in Alaskan education until the 1960s. Indigenous languages were perceived as "harmful" to the processes of civilization of indigenous populations. Christianity was considered incompatible with any other language except English, or with any other culture except Western European/American culture ${ }^{26}$. This led to the situation in which representatives of indige-

${ }^{23}$ WILliamS, M.S.T., The Comity Agreement: Missionization of Alaska Native People, [in:] The Alaska Native Reader. History, Culture. Politics, ed. WILLIAMS, M.S.T., Durham 2009, p. 154.

${ }^{24}$ FIENUP-RIORDAN, A., The Yupiit of Western Alaska, [in:] Endangered Peoples of the Arctic. Struggles to Survive and Thrive, ed. FREEMAN, M.M.R., Westport 2000, p. 253.

25 WILliamS, M.S.T., The Comity Agreement..., pp. 155-156.

${ }^{26}$ VAKHTIN, N., The Russian Arctic between Missionaries and Soviets: The Return of Religion, Double Belief, or Double Identity?, [in:] Rebuilding Identities. Pathways to Reform in Post-Soviet Siberia, ed. KASTEN, E., Halle 2005, pp. 30-31. 
nous groups were forced not only to choose the language itself, but in fact to code-switching, depending on the external expectations of the colonizers ${ }^{27}$.

The activity of the Russian-American Company, which with the consent of the Tsar of Russia monopolized the extraction of natural resources in this area, also contributed to the development of missionary schools. The Company started technical training of the ingenious inhabitants of Alaska and individuals from mixed-race families. The purpose of the established vocational schools was to use the local workforce for the needs of the Company, as well as "Christianisation" and "civilization" of indigenous residents. Since the sale of Alaska and its transition to US jurisdiction, vocational schools run by the Russian-American Company have been closed. Whereas, missionary schools continued to operate (some of them until 1916), receiving support from the Russian government ${ }^{28}$.

The development of schools in the following decades after 1867 was related to missionary activities (carried out mainly by the Protestant and Roman Catholic church) - supported by state institutions embodied by military administration. Their goals were unambiguous - like in previous decades - Christianization and civilization of indigenous populations. In this context, religious indoctrination was perceived as the most effective means of "civilization" of the natives. The territory of Alaska was divided into missionary regions, in which missionaries representing particular denominations conducted their activities $^{29}$. Indigenous beliefs blended with new faith (e.g. the idea of sin replaced the old taboo), and the old shamanic rituals were replaced by new Christian symbolism (spells were replaced by miracles, songs by prayers). For example, the missionaries forbade hunting on Sunday, which was associated by the Eskimos from North Slope with old taboos ${ }^{30}$.

Religious schools in Alaska were based on a law passed in 1819 on American Indians [Civilization Fund Act]. This law gave the US government virtually unlimited opportunities to make decisions about almost all aspects of the life of indigenous populations (including education, religion, medicine, law, hunting and fishing, as well as the disposal of land and its resources). When Alaska came under American jurisdiction, the impact of the act on indigenous populations living in this state was extended ${ }^{31}$.

In 1884, the first legal act regarding Alaska [Organic Act] was developed. It regulated the functioning of federal authorities and provided legal grounds for the creation of a school system. At the end of the 19th century, the federal government established dai-

27 Ibidem, p. 33.

${ }^{28}$ Report of the Education task Force, Alaska Natives Commission/Alaska Federation of Natives, 1995, [in:] Alaska Native Education..., p. 8.

${ }^{29}$ KLAUSNER, S.Z., FOULKS, E.F., Eskimo Capitalists. Oil, Politics and Alcohol, New Jersey 1982, p. 36 .

${ }^{30}$ CHANCE, N.A., The Iñupiat and Arctic Alaska. An Ethnography of Development, Montreal 1990, p. 47.

31 BARNHARD, C., A History of Schooling for Alaska Native People..., pp. 5-6. 
ly schools in most settlements, and started the process of establishing vocational schools with boarding houses. At that time, $99 \%$ of students were natives ${ }^{32}$.

It is worth paying attention to the policy of creating a dual school system in Alaska. Creating a separate system (racially segregated) for white children and children from indigenous ethnic groups had several causes. One of them was the expansion of non-indigenous white population in the larger cities of Alaska. Its representatives wanted to create separate schools for their own children. Another reason was the reluctance of the authorities of the territory to finance education of the natives (which was imposed on the local authorities by the federal state authorities). It resulted, among others, from the Nelson Act passed by the Congress in 1905, which assumed the creation of schools in all Alaska settlements. In 1912, Congress passed the Second Organic Act. One of its elements was the creation of foundations for the territorial management of schools. And although, on the basis of the new legal act, the Territorial Legislature did not have the possibility to change the provisions of the existing American Educational Law, in 1915 they attempted to create their own homogeneous school system. However, it was a system that did not include schools for minority representatives, as the local authorities were reluctant to maintain schools for the natives. As a result of legal provisions, in 1917 the legal status of schools in Alaska was sanctioned to exclude indigenous schools from the jurisdiction of territorial authorities and in fact creating a segregated school system ${ }^{33}$.

Consequently, a dual education system managed by two institutions was created. On the one hand, there was a system for white children and a certain (small) part of mixedrace children - managed by the authorities of the territory. On the other hand, a school system managed by the Federal Bureau of Education was established. The goal of the Bureau of Education was fast assimilation of indigenous populations in the mainstream of the American value system. It is worth noting that the process of assimilation through education was conducted without any recognition of differences between the different groups inhabiting Alaska, as well as their culture and language ${ }^{34}$. Such goals of the education system in Alaska were in line with the policy of education authorities at the national level. In this context, W. Churchill states that regardless of whether the entity running the boarding school was a state or a church, their results were the same at every moment of their creation and in each place. Their task was to "deculturate" and "denationalize" children from indigenous communities and introduce them to Western culture - turning them into small white people ${ }^{35}$. Such actions were taken in all areas of the USA against American Indians, according to the principle: kill the Indian, save the man (or in other words: removing an

32 Report of the Education task Force, Alaska Natives Commission/Alaska Federation of Natives, 1995, [in:] Alaska Native Education..., p. 8.

33 Ibidem, p. 10.

34 BARNHARD, C., A History of Schooling for Alaska Native People..., pp. 6-7.

${ }^{35}$ CHURCHILL, W., Kill the Indian, Save the Man. The Genocidal Impact of American Indian Residential Schools, San Francisco 2004, p. 28. 
Indian to create a man). According to this assumption, an Indian cannot be a human being. If he is to be a human, then he cannot remain an Indian ${ }^{36}$.

In 1917, 46 territorial schools were established in rural areas educating 1162 students. At the same time, 71 rural federal schools were formed to educate 3,500 pupils. In reality, however, the Alaska segregation system did not develop in the directions planned during its creation. Financial issues were at the root of abandoning the practice of duplicating schools in small rural communities. In many of them, both white children and those from indigenous minorities were educated. It should be noted that educational programs in federal schools (as opposed to those in institutions run by territorial authorities) included selected indigenous contents (such as dancing or games) ${ }^{37}$.

It is worth noting that the development of the United States' educational policy towards ethnic minorities in Alaska was in some respects different from that of the remaining 48 states. On the other hand, since the United States bought Alaska from Russia in 1867, the political activities, programs and relationships that were developed between the government and American Indians began to have a significant impact also on the indigenous population of Alaska. It must be added that a significant part of the educational policy solutions was not created for the indigenous people of Alaska, nor in the context of conditions prevailing in this state. For the most part, the policy towards the Indians had a significant impact on the functioning of education in Alaska. In addition, as C. Barhardt points out, the policy, created in this earliest period, laid the groundwork for state schooling practices for indigenous Alaska populations that are present to this day ${ }^{38}$.

From 1931, activities undertaken by the Federal Bureau of Education concerned not only maintaining the school system in the least urbanized areas of Alaska, but also developing medical care, organization of reindeer husbandry (whose aim was to transform the existing ways of managing indigenous groups), creating retail chains, functioning of the coastal fleet [North Star] (the aim of which was to provide for the most isolated settlements on the coast, as well as care for orphans). The Bureau of Education also created new educational institutions (including several vocational schools) ${ }^{39}$.

The adoption of the Indian Reorganization Act (IRA) in 1934 changed the assumptions of American educational policy towards minorities. The new law made it possible to create indigenous, tribal institutions, as well as to conduct business activities by representatives of ethnic groups. The purpose of the changes was to increase their self-sufficiency $^{40}$.

In the 1930s, the activities of the Congress were aimed at creating an educational policy that would, on the one hand, integrate indigenous ethnic groups into Western culture

${ }^{36}$ Ibidem, pp. 13-14.

${ }^{37}$ Report of the Education task Force, Alaska Natives Commission/Alaska Federation of Natives, 1995, [in:] Alaska Native Education..., pp. 10-11.

38 BARNHARD, C., A History of Schooling for Alaska Native People..., p. 3.

39 Report of the Education task Force, p. 11.

${ }^{40}$ CHANCE, N.A., The Iñupiat and Arctic Alaska..., p. 53. 
and, on the other, preserve indigenous culture. Such progressive views (connected with the perception of ethnic communities as cultural entities and the necessity of their integration and development of their own self-government), were represented, among others, by the Commissioner for Indian Affairs, John Collier. In reality, however, the assumptions of the proposed policy had little chance of success. The great landowners, along with the conservative Congress, torpedoed most of the ideas and proposed legal solutions ${ }^{41}$. Inadequate funding of territorial schools from federal funds (schools which educated a significant portion of children from indigenous communities) resulted in the fact that Alaska's territorial authorities became reluctant regarding their conduct and maintenance. In 1939, 18 such schools were handed over to the authorities of the Bureau of Indian Affairs ${ }^{42}$.

\section{Post-war education policy in Alaska}

The beginning of the 1940s (and related military operations) caused an intensification of contacts between indigenous peoples and other representatives of American society. At that time, a new assimilation policy was started. It assumed undertaking intensified assimilation activities towards selected individuals from indigenous communities (instead of influencing entire groups). At the same time, activities were undertaken in the field of education of children from indigenous groups, either in education for white people or in separate institutions (in line with the "separate but equal" principle). After the end of the war, territorial authorities proposed the creation of a homogeneous education system, with a common training program for all students. The Federal Bureau of Indian Affairs, however, sought to continue a separate school system for the indigenous population of Alaska ${ }^{43}$.

The policy of individual assimilation (started in the early 1940s) was continued. To this end, in 1947 a large secondary school was established on the site of the sea air base in Sitka. It offered both general education and various forms of vocational education. The Mount Edgecumbe School was intended for young people from indigenous ethnic groups living in the entire territory of Alaska. Efforts were also made to create boarding schools in other states. In many cases, when there were not enough places in the Mount Edgecumbe School, young people were sent to boarding schools functioning in other states ${ }^{44}$.

In the 1940s, the majority of children from indigenous groups undertook education in primary schools and ended their education at this stage. In addition, at the beginning of the 1950s, certain groups of children from indigenous communities were not covered by any school education. In subsequent years, children from areas with no schools in operation were placed in primary schools with boarding houses. The policy of the Bureau of Indian

${ }^{41}$ MAKKA, R., FLERAS, A., The Politics of Indigenity. Challenging the State in Canada and Aotearoa New Zealand, Melbourne 2005, p. 203.

\footnotetext{
${ }^{42}$ Report of the Education task Force, p. 11.

43 Ibidem, p. 12.

${ }^{44}$ Ibidem.
} 
Table 1. A chronological view of the main legal changes in the education system in Alaska in the years $1867-1976$

\begin{tabular}{|c|c|}
\hline Year & Transformations in the education system and legal acts \\
\hline 1867 & The United States bought Alaska from Russia \\
\hline 1884 & $\begin{array}{l}\text { Organic Act: The US Congress transferred the responsibility for providing education for } \\
\text { children of all races within the country, to the Bureau of Education in the Department } \\
\text { of the Interior }\end{array}$ \\
\hline 1900 & $\begin{array}{l}\text { The US Congress granted municipalities in Alaska the legal authority to create and reg- } \\
\text { ister schools and maintain them from taxes }\end{array}$ \\
\hline 1905 & $\begin{array}{l}\text { Nelson Act: The US Congress made it possible to create schools outside the associated } \\
\text { cities, and the governor of the territory became the official administrator of public ed- } \\
\text { ucation }\end{array}$ \\
\hline 1917 & $\begin{array}{l}\text { Uniform School Act: The US Congress established the Territorial Board of Education } \\
\text { and created the position of the Commissioner for Education }\end{array}$ \\
\hline 1931 & $\begin{array}{l}\text { The US Congress transferred the responsibility for indigenous education in Alaska from } \\
\text { the Bureau of Education to the Office of Indian Affairs (both within the Department of } \\
\text { the Interior) }\end{array}$ \\
\hline 1934 & $\begin{array}{l}\text { Johnson-O'Malley Act: The US Congress granted financial support to states to create ed- } \\
\text { ucation programs for natives in public schools, and also created the legal basis for the } \\
\text { functioning of services in the sphere of health, education and social affairs }\end{array}$ \\
\hline 1951 & $\begin{array}{l}\text { Johnson-O'Malley Act-development of the Act: The US Congress extended the regu- } \\
\text { lations of the Act to Alaska }\end{array}$ \\
\hline 1951 & $\begin{array}{l}\text { PL 815-874: The US Congress awarded federal funds for the functioning of schools in } \\
\text { military bases }\end{array}$ \\
\hline 1959 & The US Congress passed the Alaska Statehood Act \\
\hline 1963 & $\begin{array}{l}\text { Borough Act: the Alaska State Legislature created nine boroughs in which all education- } \\
\text { al institutions of local school districts were to function }\end{array}$ \\
\hline 1965 & $\begin{array}{l}\text { Division of State-Operated School System (SOS): The Alaska State Department of } \\
\text { Education reorganized and created a new division that transferred responsibilities to } \\
\text { schools operating in rural areas and schools operating in military bases }\end{array}$ \\
\hline 1971 & $\begin{array}{l}\text { Alaska State-Operated School System: The Legislative Body of the State of Alaska cre- } \\
\text { ated a new system as an independent agency and transferred responsibility for the func- } \\
\text { tioning of education from the Department of Education to rural schools and schools op- } \\
\text { erating in military bases }\end{array}$ \\
\hline 1975 & $\begin{array}{l}\text { Alaska Unorganized Borough School District: The Legislative Body of the State of } \\
\text { Alaska abolished the Alaska State-Operated School System, and created the Unorganized } \\
\text { Borough School District }\end{array}$ \\
\hline 1976 & $\begin{array}{l}\text { Regional Educational Attendance Areas (REAAs): The Legislative Body of the State } \\
\text { of Alaska abolished the Unorganized Borough School District and created } 21 \text { Regional } \\
\text { Educational Attendance Areas. Schools operating in military bases entered into agree- } \\
\text { ments with the nearest district or became part of REAAs. }\end{array}$ \\
\hline
\end{tabular}

Source: ORVIK, J., Cross-cultural education in Alaska, in: Education of Minorities, ed. MEGARRY, J., NISBET, S., HYDE, E., New York 1981, p. 285. 
Education was aimed not only at cutting off children and young people from their local environment, but also in many cases discouraged them from returning ${ }^{45}$.

From 1951, the Bureau of Indian Education began the process of transferring the management competencies of some schools to the territorial authorities of Alaska. This process was systematically continued after Alaska gained the status of a state in 1959, and ended only in 1985. Alaska's entry into the Union resulted in changes in the sphere of education. In 1965-1966 the State Operated School System was established, whose goal was to centrally manage rural schools in Alaska ${ }^{46}$.

In fact, it was not until the mid-1960s that critical analyses of the situation of indigenous peoples were made in the United States. Many of them were published as government reports. One of the key issues discussed in the reports was the state of indigenous education, as well as the level of population education. As a consequence of these reports, attempts to transform indigenous education were made (in subsequent decades). It should be noted that in the USA, as in Canada (and also in Scandinavia), real transformations in education for indigenous ethnic groups occurred only in the 1970s.

At least two reports are worth mentioning. The first was developed in the years 19681969 by a special Senate investigative subcommittee under the leadership of Senator Robert Kennedy (and hence is often referred to as the "Kennedy Report"). It is a critical analysis of the four decades of the education system for indigenous ethnic groups, including the practices of forced assimilation and discrimination. The title of the report published in 1969 is very meaningful and says a lot about its contents: "Indian Education: A National Tragedy - A National Challenge." The second report, developed in 1967-1971, was commissioned by the Ministry of Education of the United States. The report, under the title "National Study of American Indian Education", was developed in cooperation with eight university centres that conducted research in 26 communities (and 40 schools from various states participated in the research, including Alaska). This report was also a critical review of the educational policy of the US authorities towards indigenous peoples living in this territory ${ }^{47}$.

The consequences of these reports include transformations in the sphere of indigenous education. In 1972, a new act [Indian Education Act] was passed, the assumptions of which were directed at adjusting public education to the needs of indigenous communities. In addition, various activities were launched to develop indigenous initiatives (such as targeted grants, federal programs to finance institutions and tribal organizations), as well as the emergence of state institutions for the education of Indian children and adults. In subsequent years, laws were also created to establish indigenous educational institutions, or take over the management of individual schools [Indian Self-Determination, Education Assistance Act]. However, along with the enactment of these laws and the subsequent practice, there were many critical voices suggesting that they constitute only an indige-

\footnotetext{
${ }^{45}$ BARNHARD, C., A History of Schooling for Alaska Native People..., p. 3.

${ }^{46}$ Report of the Education task Force, p. 12.

${ }^{47}$ BARNHARD, C., A History of Schooling for Alaska Native People..., pp. 14-15.
} 
nous "illusion of control" over education, but it should be noted that in the following years the number of representatives of indigenous ethnic groups in the government bodies of the Office of Indian Affairs increased systematically ${ }^{48}$.

The legal, administrative and economic solutions related to the adoption of the Alaska Native Claims Settlement Act - ANCSA had a particular impact on the transformation in the field of indigenous education in Alaska. As a result of compensation arrangements, indigenous communities in Alaska received nearly 44 million acres of land and 962.5 million US dollars. They were given to 12 indigenous corporations that were created as part of different cultural and linguistic regions of the state. As a consequence, regional corporations became the largest landowners in Alaska. Many indigenous communities thus gained access to significant financial resources and power. At the same time, regional corporations obtained the rights to exploit natural resources, which due to the discovery and commencement of oil extraction, was associated with a share in profits from the sale of this resource ${ }^{49}$.

Regional corporations gained the right to develop and finance many institutions, such as health care or education. The law also changed the ways in which many representatives of indigenous communities perceived themselves. They ceased to be citizens of the "second category", because they became full owners of almost $12 \%$ of the territory of Alaska. On the other hand, this law deprived indigenous residents of claims against the rest (over $88 \%$ ) of the state of Alaska. In addition, in the following years, the market activity of indigenous corporations operating "for profit" became the basis for criticism ${ }^{50}$. The four decades of the functioning of the Act indicate that not all communities were able to take advantage of the opportunities and solutions created by this legal act. Some of them manage their resources responsibly. They invest profits, create foundations for future indigenous generations, and develop programs for the protection and revitalization of indigenous culture. However, some of the organizations systematically sell the land (mainly to oil companies) and distribute the funds among their members. Spending of funds for immediate needs (or even giving away money) makes the idea of preserving the property for future generations largely forgotten and wasted ${ }^{51}$.

As was already mentioned, in the late 1960s and at the beginning of the next decade, criticism of indigenous education offered by the federal authorities in Alaska was growing. This criticism was included in the aforementioned reports, which were created at the request of the US government. At the same time, many authors dealing with the issue of education of indigenous ethnic groups indicated that the state perceived indigenous education in Alaska in terms of a "problem". In particular, attention was paid to the low achieve-

\footnotetext{
${ }^{48}$ Ibidem, pp. 16-17.

49 OSHERENKO, G., YOUNG, O.R., The Age of the Arctic: hot conflicts and cold realities, Cambridge 1989 , p. 78.

50 Ibidem, p. 79.

51 PULLAR, G.L., Indigenous Self-Government and Political Institutions in Alaska, w: An Indigenous Parliament? Realities and Perspectives in Russia and the Circumpolar North, IWGIA Document No. 116, Copenhagen 2005, pp. 113-114.
} 
ments of indigenous pupils, as well as the small possibilities for continuing their education at the secondary level ${ }^{52}$.

As a consequence, federal education authorities decided to liquidate the inefficient system [State Operated School System] and replace it with a more decentralized system of school districts. In 1975, 21 regional school districts were created, the aim of which was to increase local control over education. Community School Committees replaced regional school councils. Their aim was to extend the influence of local communities on school management. This meant a change in federal policy towards indigenous communities. From that time, the influence of indigenous organizations on education, as well as the selection of school committees members, was to increase ${ }^{53}$.

At the end of the 1970s, activities were also undertaken to develop the secondary school network. The development of this education sector in the 1960s was stopped at the beginning of the 1970s. The reason for the stagnation was, on the one hand, associated with the difficulties of indigenous young people returning from boarding schools to family settlements - in finding jobs and a "way of life". On the other hand, there had been many mental and psychological problems associated with the spreading of alcoholism, as well as the dramatically increasing level of suicides among young people. This influenced the decline of the concept of development of the regional secondary school system. The changes that occurred at the end of the 1970s resulted in a return to this concept. Consequently, in most of the towns with primary schools in operation, secondary schools were also established in an attempt to provide all students with the constitutional right to 12 years of education $(\mathrm{K}-12)^{54}$.

Although the development of education in the following decades was conducive to equalizing the educational opportunities of children and youth coming from indigenous minorities, at the same time, there existed (and still exist) many obstacles in obtaining similar results. There are many reasons for the educational failures of students, which are related to the specificity of the problems of native education in Alaska. These include, above all, a small number of teachers who understand the specificity of working with native students (including indigenous teachers), a high teacher turnover ratio, a culturally alien school environment, lack of relationship between educational programs and the realities of life in arctic areas, discrepancies between education objectives in "Western" education and those that arise from the needs of local communities, a low level of pupils' educational aspirations, a generally low level of equipment of small rural schools (in which a large part of the Alaskan indigenous population is educated), as well as social factors (including poverty and addiction $)^{55}$.

Today, three types of schools can be distinguished in Alaska. The first include schools operating in rural areas. They are attended primarily by students from the indigenous

52 SZASZ, M., Education and the American Indian: the Road to Self-determination Since 1928, Albuquerque 1974, pp. 127-128.

${ }^{53}$ Report of the Education task Force, pp. 12-13.

54 Ibidem, p. 13.

${ }^{55}$ Ibidem, pp. 16-19. 
Alaska community. Most of these schools function based on a twelve-grade education system (K-12). Due to a small number of students, education is organized in a way that allows the teacher to work with students of different ages in the same group (several classes in one). For the same reason, such schools employ only a few teachers (their number may vary from 1 to 10 in each school). Usually, in the first years, education is organized based on an indigenous language (e.g. Alutiiq, Cupik, Gwichin, Inupiat, Siberian Jupik, Tlingit or Middle Jupik). In some cases, individual schools apply education programs largely focused on indigenous content (including language, learning goals and traditional knowledge). In certain districts, such content may also be included in generally applicable education programs. An important aspect of the functioning of rural schools is the inclusion of members of local communities in the education process; they also act as support for language teachers. Most teachers from indigenous communities are employed in these types of schools. It should be stated that the percentage of students graduating from secondary schools in rural areas is much lower than in cities.

The second type are schools in rural regional centres and/or located in the system of roads or waterways [Rural Regional Centre and Road System/Marine Highway Schools]. These schools function - like the schools of the first type - at primary and secondary level. These are much larger institutions, operating on the one hand in regional centres (such as Barrow, Bethel, Kotzebue or Nome). These towns are inhabited primarily by the indigenous population together with a large group (approx. 30-50\%) of the non-indigenous population. Schools of this type also operate in towns located on the road and water transport routes accessible through a car or ferry (such as Kenai, Ketchikan, Sitka or Tok). These towns are inhabited mainly by non-indigenous populations. Schools of the second type combine the characteristics of municipal and rural schools and are managed - like rural schools - by the authorities of specific districts or regions included in the Regional Educational Attendance Areas (REAA). The educational programs of these schools are aimed at individuals from indigenous groups, but their scope and content depends on the number of such students in specific institutions.

The third type are schools functioning in cities. We are talking mainly about the three largest cities of Alaska (Anchorage, Fairbanks and Juneau). Schools of this type function similarly to institutions in other areas of the United States. They educate a very diverse ethnic and linguistic population of students, with students from indigenous Alaska being the largest ethnic minority. Most schools of this type have at least one program oriented on representatives of indigenous groups (both the Eskimo minorities and American Indians). Such programs are funded by federal funds (for example under the Johnson-O'Malley Act or the Indian Education Act). In some cases, they are supported by state funds or through individual districts. Programs oriented on the indigenous cultural heritage include special intra-school educational guidance for minority students, celebrating indigenous holidays and events, or activities related to the tradition and culture of indigenous communities ${ }^{56}$.

${ }^{56}$ C. BARNHARD, A History of Schooling for Alaska Native People..., pp. 22-23. 
Starting from the 1970s, steps were taken to revitalize indigenous communities, their culture and language ${ }^{57}$. Most of these actions were "grassroot" projects - taken by indigenous organizations that were systematically established in Alaska. From this perspective, education was perceived as the most effective means of activating local communities, as well as the revival of indigenous values, language and traditions ${ }^{58}$.

In some cases, the activities of indigenous organizations were aimed at creating indigenous educational programs that comprehensively pursued the goals of revitalizing ethnic culture. An example is the X-CED (Cross-Cultural Education Development Program) program (created in Bristol Bay). The aim of the program was to create opportunities for educating indigenous teachers in their own local environment ${ }^{59}$.

Teaching and learning processes in the indigenous Alaska communities were therefore - according to the assumptions of the X-CED program - to be fundamentally transformed. Their main goal was to become detached from the "western" style of education and bring them closer to the "traditional" style of education and upbringing. An extremely important element of the change was also the revitalization of the culture of arctic communities ${ }^{60}$.

Many goals have been implemented several years after the start of the program (e.g. dozens of teachers of indigenous education were educated). Also from the perspective of the three decades of the program's operation, it can be stated that it has become crucial for the functioning of indigenous education in many areas inhabited by communities in Alaska. It was perfectly noticeable in the Jupik communities, in which many indigenous teachers appeared who were educated as part of the program. The creation of the Ciulistet organization in 1986 was extremely important for the development of education of teachers originating from indigenous Jupik communities and living in these areas. This society of indigenous teachers from the moment of its establishment undertook integrated activities for the preservation and revitalization of the indigenous Jupik culture and language. At the same time, the aim of the action was to support indigenous teachers in their work (both in the field of creating teaching materials, developing educational programs, and developing relations between schools and the local community $)^{61}$.

Also the next decades, up to modern times, were a time in which the existing solutions were developed and new solutions in the sphere of indigenous education were introduced. For example, in the 1990s, apart from efforts to revitalize threatened languages, develop traditional forms and curricula, extensive initiatives were undertaken in the field of documentation, development and integration of indigenous knowledge. One of the most

${ }^{57}$ E. AHGEAK MACLEAN, Culture and Change for Iñupiat and Yup'ik People of Alaska, [in:] Alaska Native Education..., p. 57.

58 LIPKA, J., Transforming Schooling: From Possibilities to Actuality?, [in:] Transforming..., p. 190.

59 ORVIK, J., Cross-cultural education in Alaska, [in:] Education of Minorities, ed. MEGARRY, J., NISBET, S., HYDE, E., New York 1981, p. 291.

60 Ibidem.

${ }^{61}$ LIPKA, J., Transforming Schooling: From Possibilities to Actuality?, [in:] Transforming the Culture of Schools. Yup'ik Eskimo Examples, ed. LIPKA, J., MOHATT, G.V., London 1998, pp. 189-191. 


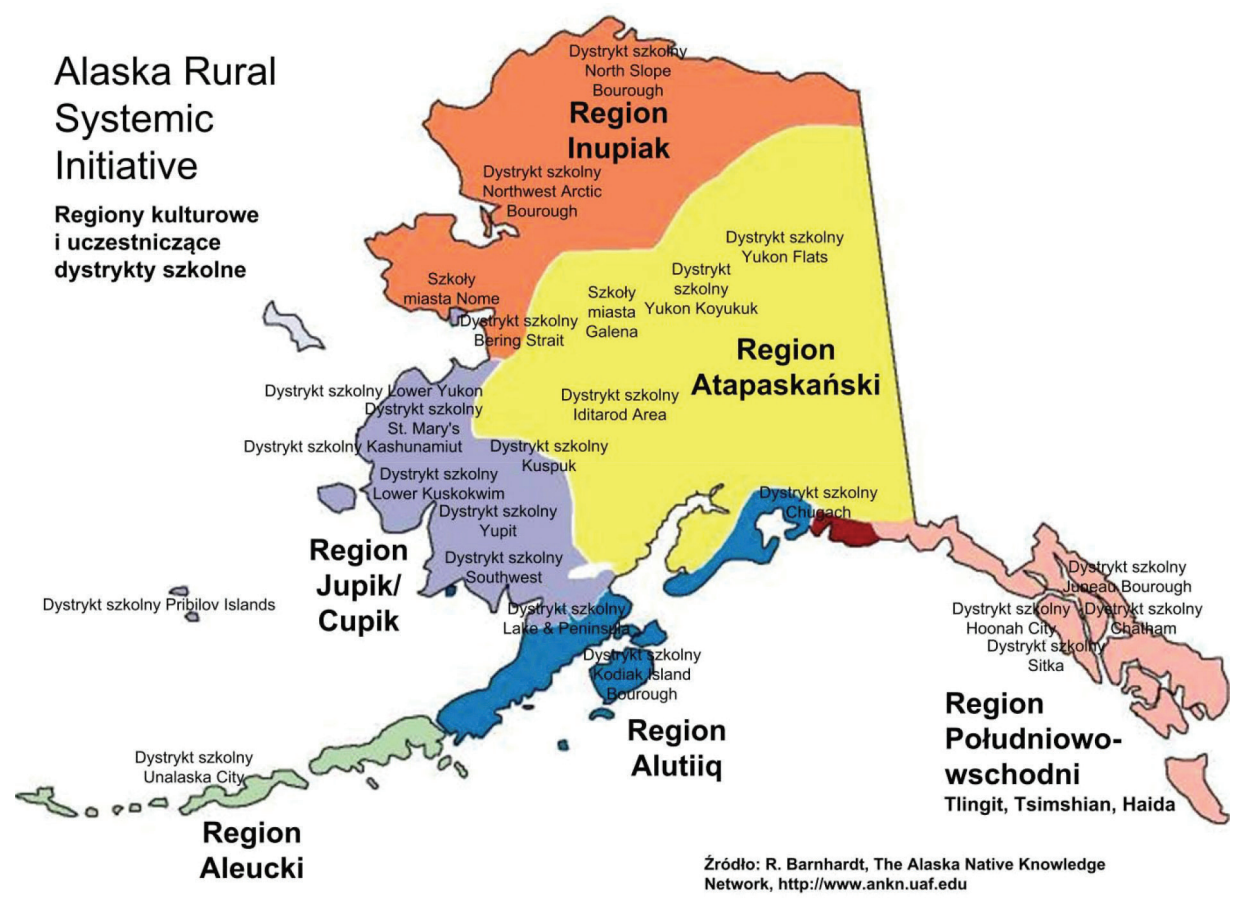

Map 2. School districts and institutions (within cultural regions), participating in the Alaska Rural Systemic Initiative - AKRSI

important initiatives started in the early 1990s was the strategy of reforming indigenous education, called the Alaska Rural Systemic Initiative (AKRSI). Activities to create the organization were implemented in 1994. It brings together more than 50 organizations working for education in rural areas of Alaska. Institutional support for this initiative was provided by the Alaska Federation of Natives and the University of Alaska Fairbanks, along with the funds of state and local government organizations ${ }^{62}$.

Activities undertaken locally by individual schools and indigenous organizations were coordinated at the level of the AKRSI organization. At the same time, thematic activities were undertaken each year, the aim of which was to introduce integrated activities in all cooperating institutions and areas of Alaska. It is worth pointing out examples of such thematic activities: 1) documentation of cultural/scientific knowledge; 2) the practice of indigenous teaching; 3 ) integration of the cultural education program with educational standards; 4) organization of teacher support systems; 5) creating culturally appropriate assessment practices ${ }^{63}$.

${ }^{62}$ BARNHARDT, R., KAWAGLEY, A.O., Culture, Chaos and Complexity. Catalysts for Change in Indigenous Education, w: Alaska Native Education..., pp. 200-201.

${ }^{63}$ Ibidem, p. 208. 
In addition, the development of the Alaska Native Knowledge Network began. It allowed to undertake multifaceted activities to create an integrated system of knowledge and organization, based on documentation and educational materials - serving the indigenous populations of Alaska.

In conclusion, the extremely important role of the Alaskan language protection and revitalization program conducted in higher education institutions is notworthy ${ }^{64}$. The Alaska Native Language Centre, functioning at the University of Fairbanks, plays a key role in documenting and revitalizing disappearing languages ${ }^{65}$.

\section{Bibliography}

AHGEAK MACLEAN, E., Culture and Change for Iñupiat and Yup'ik People of Alaska, in: Alaska Native Education. Views From Within, ed. BARNHARDT, R., KAWAGLEY, A.O., Fairbanks 2010.

Alaska Native Language Center Mission and Goal, website: Alaska Native Language Center, University of Alaska Fairbanks, website: http://www.uaf.edu/anlc/mission/.

BARNHARD, C., A History of Schooling for Alaska Native People, „Journal of American Indian Education" 2001, vol. 40, no 1.

BARNHARDT, R., KAWAGLEY, A.O., Culture, Chaos and Complexity. Catalysts for Change in Indigenous Education, in: Alaska Native Education. Views From Within, ed. BARNHARDT, R., KAWAGLEY, A.O., Fairbanks 2010.

BURCH, E.S., Social Life in Northwest Alaska. The Structure of Iñupiaq Eskimo Nations, Fairbanks 2006.

BURCH, E.S., The Iñupiaq Eskimo Nations of Northwest Alaska, Fairbanks 1998.

CHANCE, N.A., The Iñupiat and Arctic Alaska. An Ethnography of Development, Montreal 1990.

CHURCHILL, W., Kill the Indian, Save the Man. The Genocidal Impact of American Indian Residential Schools, San Francisco 2004.

FIENUP-RIORDAN, A., The Yupiit of Western Alaska, in: Endangered Peoples of the Arctic. Struggles to Survive and Thrive, ed. FREEMAN, M.M.R., Westport 2000.

GRABURN, N.H.H,. STRONG, B.S., Circumpolar Peoples: An Anthropological Perspective, "Pacific Palisades" 1973.

JAHN, A., Alaska, Warsaw 1966.

JENNINGS, M.L., COLliER, J.R., One University, Two Universes: Alaska Natives and the University of Alaska-Anchorage, in: Native American Studies in Higher Education. Models for Collaboration between Universities and Indigenous Nations, ed. CHAMPAGNE, D., STAUSS, J., Walnut Creek 2002, pp. 208-225.

KLAUSNER, S.Z., FOULKS, E.F., Eskimo Capitalists. Oil, Politics and Alcohol, New Jersey 1982.

KRAUSS, M.E., Alaska Native Languages: Past, Present, Future, Fairbanks 1980.

LIPKA, J., Transforming Schooling: From Possibilities to Actuality?, in: Transforming the Culture of Schools. Yup'ik Eskimo Examples, ed. LIPKA, J., MOHATT, G.V., London 1998.

${ }^{64}$ JENNINGS, M.L., COLLIER, J.R., One University, Two Universes: Alaska Natives and the University of Alaska-Anchorage, [in:] Native American Studies in Higher Education. Models for Collaboration between Universities and Indigenous Nations, ed. CHAMPAGNE, D., STAUSS, J., Walnut Creek 2002, pp. $208-225$.

${ }^{65}$ See. Alaska Native Language Center Mission and Goal, website: Alaska Native Language Center, University of Alaska Fairbanks, website: http://www.uaf.edu/anlc/mission/ 
MAKKA, R., FLERAS, A., The Politics of Indigenity. Challenging the State in Canada and Aotearoa New Zealand, Melbourne 2005.

NORRIS, T., VINES, P.L., HOEFFEL, E.M., The American Indian and Alaska Native Population: 2010, 2010 Census Briefs, United States Department of Commerce Economics and Statistics Administration, U.S. Census Bureau, website: http://www.census.gov/prod/cen2010/briefs/ c2010br-10.pdf.

OLCHOWIK-ADAMOWSKA L., BIERNACKA E., Indianie Ameryki Pótnocnej, the series Mitologie Świata, Warsaw 2007.

ORVIK, J., Cross-cultural education in Alaska, in: Education of Minorities, ed. MEGARRY, J., NISBET, S., HYDE, E., New York 1981.

OSHERENKO, G., YOUNG, O.R., The Age of the Arctic: hot conflicts and cold realities, Cambridge 1989.

PULLAR, G.L., Indigenous Self-Government and Political Institutions in Alaska, in: An Indigenous Parliament? Realities and Perspectives in Russia and the Circumpolar North, IWGIA Document No. 116, Copenhagen 2005.

Report of the Education task Force, Alaska Natives Commission/Alaska Federation of Natives, 1995, in: Alaska Native Education. Views From Within, ed. BARNHARDT, R., KAWAGLEY, A.O., Fairbanks 2010.

ROWLEY, S.D.M., Inua: Spirit World of the Bering Sea Eskimo, Washington 1988.

SZASZ, M., Education and the American Indian: the Road to Self-determination Since 1928, Albuquerque 1974.

VAKHTIN, N., The Russian Arctic between Missionaries and Soviets: The Return of Religion, Double Belief, or Double Identity?, in: Rebuilding Identities. Pathways to Reform in PostSoviet Siberia, ed. KASTEN, E., Halle 2005.

WALENDZIAK, T., Eskimosi, the series Mitologie Świata, Warsaw 2008.

WILliAMS, M.S.T., The Comity Agreement: Missionization of Alaska Native People, in: The Alaska Native Reader. History, Culture. Politics, ed. WILliAMS, M.S.T., Durham 2009. 
